\title{
SELECTION OF MESOCOSM TO REMOVE NUTRIENTS WITH CONSTRUCTED WETLANDS
}

\author{
Mosisa Teferi Timotewos' ${ }^{1}$, Kinfe Kassa' ${ }^{1}$ Daniel Reddythota ${ }^{1 *}$ \\ 1 Department of Water Supply and Environmental Engineering, Arba Minch University, Arba Minch, Ethiopia \\ * Corresponding author's e-mail: daniel.reddy@amu.edu.et
}

Received: 2017.04.05

Accepted: 2017.06.04

Published: 2017.07.01

\begin{abstract}
Oxidizing bacteria in the roots of the plant has a unique ability of absorbing pollutants in the wastewater, thus they considered as a useful method for wastewater treatment. Using three plants, namely Typha, Phragmites australis, and Scirpus, we performed a series of mesocosms experiments in Arba Minch, Ethiopia for the removal of nutrients by constructed wetlands. We observed that the nutrients reached the removal efficiencies of $99.1 \%$ for Typha plant, has better removal efficiency than Phragmites australis and Scirpus. The results explore the oxidizing bacteria activity in different plants and that led to enhance the removal efficiency of pollutants in wastewater.
\end{abstract}

Keywords: constructed wetland, horizontal subsurface flow wetland, Typha, nutrients

\section{INTRODUCTION}

Biological nitrification and de-nitrification process in the plant roots is the most prominent phenomena for the removal of nitrogen from wastewater by employing constructed wetlands. In particular, the uptake capacity of emergent macrophytes is lower, although it is an environmentally friendly and clean process. If wetlands are not harvested, vast majority of nutrients are incorporated into plant tissues which will return to the water by decomposition process. Contrastingly, biological nitrification-denitrification process depends on various factors, such as temperature, $\mathrm{pH}$, alkalinity and, above all, electron and dissolved oxygen (DO) availability. The removal of $\mathrm{NH}_{3}-\mathrm{N}$ is largely dependent on $\mathrm{O}_{2}$ supply. The bed medium is continuously water-saturated and therefore generally anaerobic. The plants transport $\mathrm{O}_{2}$ to the rhizosphere, thereby creating aerobic micro sites, adjacent to the roots and rhizomes where $\mathrm{NH}_{4}^{+}$will be oxidized first to nitrite by nitrifying bacteria, such as Nitrosomonas and then to nitrate by bacteria with the same enzymatic equipment as Nitrobacter. After diffusion in an anaerobic zone of the wetland and in the presence of an electron source, such as lactate or hydrogen gas, nitrates will serve as an electron sink for a very large family of bacteria called nitrate reducers [Shubiao $\mathrm{Wu}$ et al., 2014]. Nitrate is finally reduced to $\mathrm{N}_{2}$ and emitted into the atmosphere [Drio et al., 1997]. The rate of nitrification is significantly lower than that of denitrification and, in fact, becomes the limiting factor for controlling nitrogen removal. When $1 \mathrm{~g}$ of $\mathrm{NH}_{3}-\mathrm{N}$ is oxidized to beNO ${ }_{3}-\mathrm{N}, 4.3 \mathrm{~g}$ of oxygen is required. For $\mathrm{NH}_{3}-\mathrm{N}$ with a concentration of $1 \mathrm{mg} / \mathrm{L}$, nitrification will not occur successfully until DO reaches $4.6 \mathrm{mg} / \mathrm{L}$. The mineralization of the excess influent BOD likely depleted the available oxygen and retarded nitrification.

Wastewater collection and treatment are problematic in Ethiopia due to mountainous terrain, dispersed population, and a lower economic base. Due to scarce resources, in economically developing rural areas adopting wastewater treatment, the treatment technologies must be costeffective and easy to adopt, require less energy input and maintenance costs, and be capable of meeting effluent discharge standards. In these situations, a Constructed wetlands (CWs) can be potentially used to enhance the overall biological performance, or can be an alternative to the conventional biological treatment [Daniels, 2001a; 
Daniels, 2001b; Kucuk et al., 2003].They have been proven to constitute a cost-effective alternative to conventional wastewater treatment mainly for small decentralized communities [Cristina et al., 2007, Dong Qing Zhang et al., 2014].

Constructed wetlands have the potential to treat a variety of wastewaters by removing organics, suspended solids, pathogens, nutrients and heavy metals [Antoniasdis, 2007]. A constructed wetland is a natural biological treatment process that is normally used to treat a variety of wastewater such as sewage [Srinivasan Nerrala, 2000, Abbas Al-Omari 2003, Ciria 2005, Keffala, 2005], polluted river [Shuh-Ren Jing, 2001, Ruan, 2006], farmyard runoff [Scholz, 2007], landfill leachate [Variga Sawaittayolthin, 2007], swine effluent [Chi-Yuan Lee, 2004], dairy parlor wastewater [Mantori, 2005] and residual dye bath [Ojstrsek et al., 2007]. As the wastewater flows through the constructed wetland, it is treated by various processes of sedimentation, filtration, oxidation [Grafias et al., 2010], reduction, adsorption, precipitation, bacterial metabolism, nitrification, denitrification, and plant uptake [Day et al., 2004].

The preference of plant species plays a vital role in CWs, as they must survive the potential toxic effects of the wastewater and its variability. The treatment process should not to be an ecotoxic but eco-friendly. It must be reducing energy usage, minimizing greenhouse gas emissions, and minimizing unwanted/harmful by-products. Water recycling projects produce positive externalities [Sala et al. 2004].

In this article we present three different plant species in constructed wetlands for treating wastewater at southern part of Ethiopia. Ten pilot units with horizontal subsurface flow have been designed and constructed to evaluate treatment performance and plant survival when subjected to same hydraulic loading rates (HLRs) for the period of 4 months. The influence of various parameters such nutrient storage in plant biomass, crop co-efficiency, water use of plant species and evapotranspiration on water treatment and/or plant growth were studied.

\section{METHODOLOGY}

\section{Mesocosms and pilot scale experimental setup}

A series of 10 mesocosms experiments were conducted during the period of May to August 2012 (Southern Ethiopia early autumn) at the ArbaMinch Research demonstration site in ArbaMinch, in the Southern nation of Ethiopia (6'04'N; 37'34'E) at an elevation of $1202 \mathrm{~m}$ above sea level. The experiments were carried out in ten plastic cylindrical tanks $\left(0.2 \mathrm{~m}^{2} \times 0.78 \mathrm{~m}\right.$ depth; gravel size range of $9.2-19 \mathrm{~mm}$ up to $0.45 \mathrm{~m}$ height) at the bottom of the plastic containers $6 \mathrm{~mm}$ wide PVC pipe was connected to monitor the level of water in the gravel media. The valve was installed at the base of each mesocosms to allow for drainage as well as water sampling. The sight gauges were covered with textile sleeve in order to exclude light and avoid the growth of algae. The ten wetland mesocosms were designed to provide conditions similar in a horizontal subsurface flow wetland (Fig. 1). The gravel was filled and the pore spaces were filled with water on $18^{\text {th }}$ April. The water level was three centimeters below the surface of the gravel.

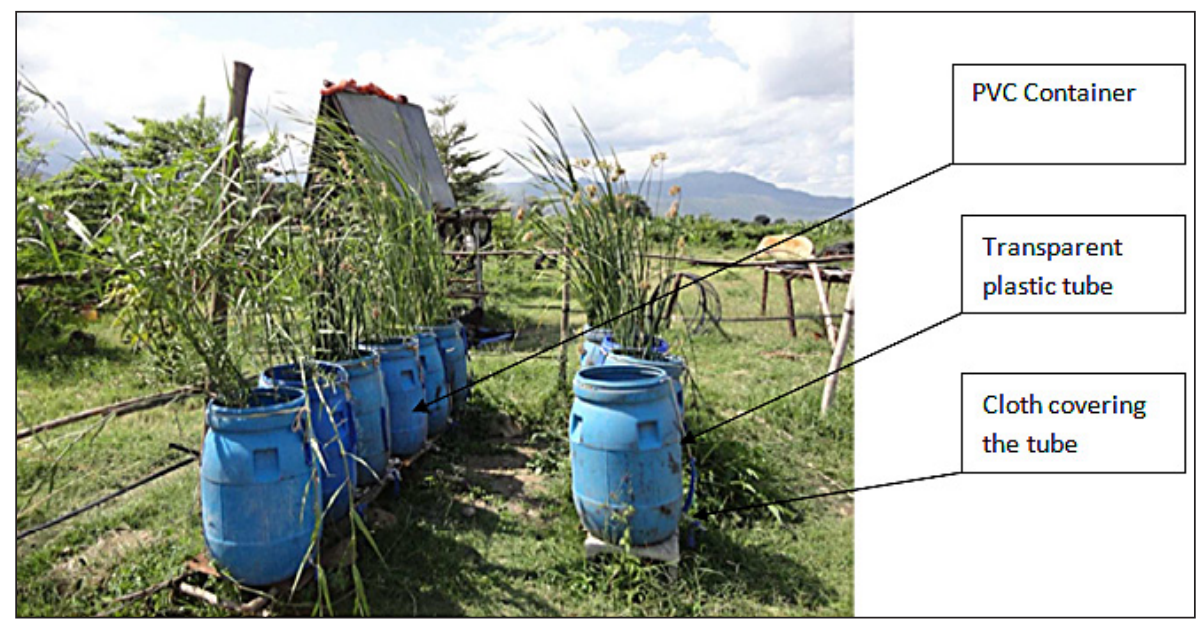

Figure 1. Pilot scale constructed wetland setup and plant growth 
Typha Angustifolia and Scirpus Riparius were collected from Abaya lake wetland, which is very near the experiment site and Phragmites Australis collected from River Kako $250 \mathrm{~km}$ from the ArbaMinch. These plants were selected because they are abundant around Abaya lake wetland as well as widely used in artificial wetlands worldwide. The plants were transported from the natural site with soil but washed out when planted in the gravel lysimeters. Three plant species were planted on $19^{\text {th }}$ April. Each species planted in three containers and 2 plant roots were planted per container. Two shoots per container were planted for Phragmites and Typha Species and 4-6 shoots per mesocosms were planted for Scirpus.

The mesocosms were loaded twice or three times a week with primary treated wastewater fetched from the waste stabilization pond of the ArbaMinch University up to the level of $3 \mathrm{~cm}$ below the gravel surface. Every five days new wastewater after collection of samples was refilled. Plant growth monitoring started after two months of planting. The growth rate and shoot height were measured once a month using a tape meter. The longest, medium and the shortest shoot heights were recorded. The representative example of each mesocosms was dried it in an oven for 48 hours and measured dry biomass of the species. Shoot density was monitored once a month by counting the number of shoots in each container and dividing by surface area of the mesocosms.

\section{Biomass monitoring}

The above ground dry biomass measurement of each set up was started early May by collecting stems of representative heights samples of above ground shoot for each species. Then the numbers of shoots in each length were counted and the total mass was calculated based on the laboratory measured samples. The number of shoots per each mesocosms was counted and multiplied by the dry weight of a single sample clump to get the dry biomass of one mesocosms. In this experiment below ground biomass was not done except at the end of the experiment. The dry weight of harvested plant samples was determined by weighing the samples after being dried in an oven until constant weight at $60^{\circ} \mathrm{C}$.

At the end of the experiment (August) a destructive harvest was conducted to determine the total dry weight of above and below ground bio- mass in each mesocosms. All of the shoots were cut at the gravel surface and removed. Then the gravel was removed and the bulk of the roots and rhizomes separated. The residual plant material was then separated through a process of wet sieving $(1 \mathrm{~mm})$ and flotation in tap water, which assisted in separating the fine roots from the gravel and also served to wash the below-ground plant material to remove humus and loosely bound nutrients. The amount of below-ground biomass in the upper $30 \mathrm{~cm}$ and lower $30 \mathrm{~cm}$ of the gravel were sampled separately. Above and below ground destructive sampling for any given mesocosm was conducted on the same day to avoid deterioration or alteration of the below ground biomass composition after the above ground biomass was removed.

The specific relationship between the shoot height and dry weight was established for each species by harvesting a number of individual shoot samples from each mesocosms spanning the full range of heights throughout the study. The height of each shoot was measured (total heights when extended straight) before determining the oven dry weight. Using this data, regression equation was derived for each species to relate the height $(\mathrm{cm})$ to dry weight $(\mathrm{g})$. The best fit function for the graph was plotted for all species. The plant shoot height and number of shoot in each mesocosms were counted every month starting from early May.

\section{Water use}

To determine the evapotranspiration rate from each mesocosms, periodic measurement of water balance was conducted from June 4, 2012 to June 30, 2012 every two days (48 hours). The volume of water Evapo-transpired was measured by refilling the mesocosms to the calibrated volume mark using a measuring cylinder. If the level of water in the container was above the mark (during wet season); the volume of water drained, to adjust the water level. Meteorological data (air temperature, rainfall data, relative humidity, solar radiation) was collected from Arba Minch University; National meteorological station located about $800 \mathrm{~m}$ from the research site.

\section{Evapotranspiration rates}

The amount of water evaporated from each mesocosms was calculated using equation 1 . The 
formula is derived from water balance equation of inflow and out flow of the mesocosms. Since they were batch loaded and there was no interaction with ground water. Therefore, the only inflow is precipitation and the regular feeding; and the out flow is ET losses. The evapotranspiration from each wetland mesocosms (ETw) for given water balance measurement period was calculated using equation 1 [Headley et al., 2010]:

$$
E T=\left[\frac{V}{A}+P\right] * \frac{1}{t}
$$

\section{Crop Coefficients}

Crop coefficient for each wetland mesocosms were calculated using equation 2 , where for a given period, the crop coefficient is the ration of ET lost form the mesocosm as a proportion of the reference ETo rate [Headley et al., 2010]:

$$
K_{E T_{0}}=\frac{E T_{w}}{E T_{0}}
$$

\section{Water Quality Analysis}

Water quality analysis was done for $\mathrm{NO}_{3}-\mathrm{N}$, $\mathrm{NH}_{4}-\mathrm{N}, \mathrm{PO}_{4}-\mathrm{P}, \mathrm{Ca}^{2+}, \mathrm{Mg}^{2+}, \mathrm{K}^{+}$and $\mathrm{BOD}_{5}$ in $\mathrm{AMU}$ water quality laboratory. $\mathrm{NO}_{3}-\mathrm{N}, \mathrm{NH}_{4}-\mathrm{N}, \mathrm{PO}_{4}-\mathrm{P}$ were analyzed using an instrument called Hach Lange DR 2800 . $\mathrm{K}^{+}$was analyzed by using a JENWAY PFP7 flame photometer instrument and $\mathrm{Ca}^{2+}$ and $\mathrm{Mg}^{2+}$ were analyzed by titration method. $\mathrm{BOD}_{5}$ was analyzed using OXITOP RESPIROMETER SYSTEMS (pressure sensors for BOD testing and measurement).

After five days the effluent water sample was collected and analyzed using the same procedure for the influent water sample. The volume of wastewater added at first and after five days was not equal because of evapotranspiration. The concentration of effluent can be increased when compared with the influent concentration. Therefore, there should be an adjustment by using a mass balance equation $\mathrm{C}_{1} \mathrm{~V}_{1}=\mathrm{C}_{2} \mathrm{~V}_{2}$ when $\mathrm{C}_{1}$ and $\mathrm{V}_{1}$ were adjusted influent concentration and its volume. While $\mathrm{C}_{2}$ and $\mathrm{V}_{2}$ was effluent concentration analyzed after five days and volume of water remaining in the container respectively. Therefore, we can calculate percentage removal by subtracting $\mathrm{C}_{1}$ from the raw wastewater analyzed in a laboratory and dividing by raw wastewater concentration and multiplied by a hundred.

\section{Statistical Analysis}

Statistical analysis of the results was conducted using SPSS package version 20 to compare the significance of differences.

\section{RESULTS AND DISCUSSION}

The performance of wetland depend upon the inflow rate, outflow rate, pollutant loading rate, hydraulic retention time(HRT), hydraulic loading rate, climatic conditions, temperature, $\mathrm{pH}$, oxygen availability, wetland design components substrate, vegetation and living organisms. The recital of Constructed wetlands is based on the plant species. Above-ground biomass production, Below-ground biomass production, shoot density, Shoot height, ET rate, Crop coefficient and water use efficiency of the plant species play a major role for the removal of pollutants in the constructed wetlands. Mean Plant biomass and water loss parameters for each species for the entire study mentioned in Table 1.

\section{Plant biomass (above and below ground biomass)}

Dry weight of biomass was analyzed twice a month on $4^{\text {th }}$ and $30^{\text {th }}$ of June. Typha species had the highest growth rate of $1.69 \mathrm{~kg} / \mathrm{m}^{2}$.Phragmites australis and Scirpus sp. had $1.28 \mathrm{~kg} / \mathrm{m}^{2}$ and 1.21 $\mathrm{kg} / \mathrm{m}^{2}$ growth rate respectively. The results of above ground biomass data were taken in order to analyze water balance and water use efficiency for the month of June. The first biomass production was much less than the biomass production taken at the end of August Month. From the results of the above ground biomass the growth rate of Scirpus was greater than Phragmites in early June due to less rainfall, but at the end of study period Phragmites had greater growth rate than Scirpus.

Below ground biomass means roots of the plant are the major component that removes unwanted materials by attachment to their surface. Root depths of each plant are different in the study. Typha had $79 \%$ of below ground biomass of the upper $30 \mathrm{~cm}$ root depth and having quite long root depth. The whole root biomass or $100 \%$ of the root was found within $30 \mathrm{~cm}$ of the root depth. This was similar to other studies where roots were the major biomass component of wetland systems) and where the majority of roots 
Table 1. Mean plant biomass and water loss parameters for each species for the entire study. Shoot density and heights are measured at August 14

\begin{tabular}{|c|c|c|c|c|c|}
\hline \multirow{2}{*}{ Parameter } & \multirow{2}{*}{ Units } & \multicolumn{4}{|c|}{ Species } \\
\hline & & Phragmites & Scirpus & Typha & Control \\
\hline Above ground biomass production & $\mathrm{g} / \mathrm{m}^{2}$ & 1284.23 & 1212.87 & 1692.66 & - \\
\hline Below ground biomass production & $\mathrm{g} / \mathrm{m}^{2}$ & 791.79 & 1456.42 & 1924.05 & - \\
\hline Shoot density & shoots $/ \mathrm{m}^{2}$ & 113.8 & 350.0 & 54.4 & - \\
\hline Max. shoot height & $\mathrm{cm}$ & 270 & 175 & 230 & - \\
\hline ET rate & $\mathrm{L} / \mathrm{m}^{2} . \mathrm{d}$ & 3.18 & 3.19 & 5.41 & 1.92 \\
\hline Crop coefficient & - & 1.05 & 1.05 & 1.77 & 0.63 \\
\hline Water Use Efficiency (Above ground biomass) & $\mathrm{g} / \mathrm{L}$ & 4.43 & 4.59 & 2.53 & - \\
\hline
\end{tabular}

were found in the top $30 \mathrm{~cm}$ of the media [Saarinen, 1996].

In the end of August above and below ground biomasses were estimated for all species. Only Phragmites australis had more above ground biomass than Scirpus and Typha, which have more below ground biomass. Typha species had the greatest below ground biomass of $2.2 \mathrm{~kg} / \mathrm{m}^{2}$. Scirpus and Phragmites has around 1.78 and $0.95 \mathrm{~kg} / \mathrm{m}^{2}$ belowground biomass respectively. That means the ratio of below ground to above ground biomass for Phragmites was less than one $(\mathrm{BG}: \mathrm{AG}=0.74)$ and the Scirpus and Typha had greater than one as 1.47 and 1.31 respectively.(Fig. 2). The percentage of the below-ground that occurred in the upper $30 \mathrm{~cm}$ of the gravel is shown above the column for each species.

\section{Growth characteristics of the plants}

The mean shoot density of the three species increased over the study period. Scirpus has the highest shoot density of 350 shoots $/ \mathrm{m}^{2}$ on August

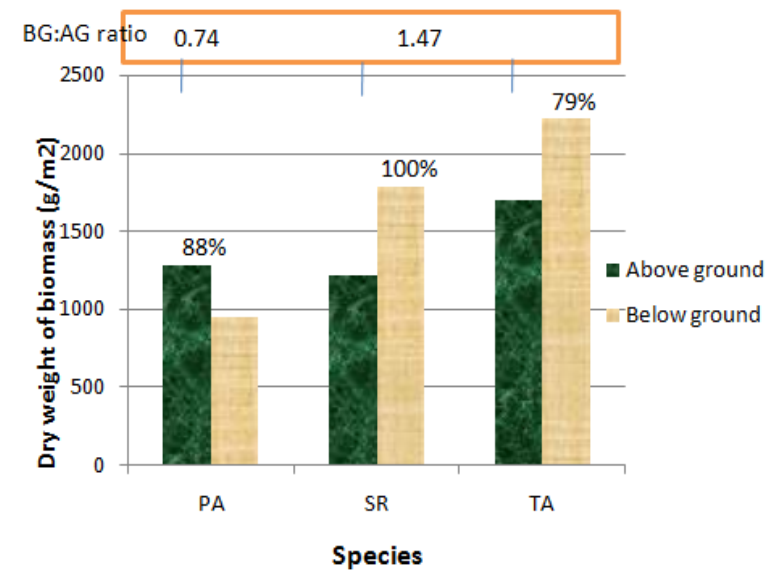

Figure 2. Mean above and below-ground biomass of each species at the end of the study $14^{\text {th }}$. Typha and Scirpus increasing shoot density throughout the study period. Typha Species grows relatively small shoot density but it had very high growth rate. At August 14 Typha and Phragmites had shoot density of 54.4 shoots $/ \mathrm{m}^{2}$ and 113.8 shoots $/ \mathrm{m}^{2}$ respectively (Fig. 3 ).

Plant shoot height increases gradually for all species throughout the study. Phragmites had the highest shoot length of $270 \mathrm{~cm}$ at the end of the study period. Scirpus and Typha had shoot length of 175 and $230 \mathrm{~cm}$ respectively in August.

Shoot density and height will influence the evapotranspiration rate, due to the presence of pores on leaves. Monitoring quantitative comparison such as shoot density and shoot height might help us in managing our land and treating much amount of wastewater on small space of land. Because Wetlands for waste water treatment may require large amount of land cover. The shoot height and plant dry biomass relationship were determined and the exponential function was found to give the best fit for all the plant species. The $\mathrm{R}^{2}$ value for all species was higher

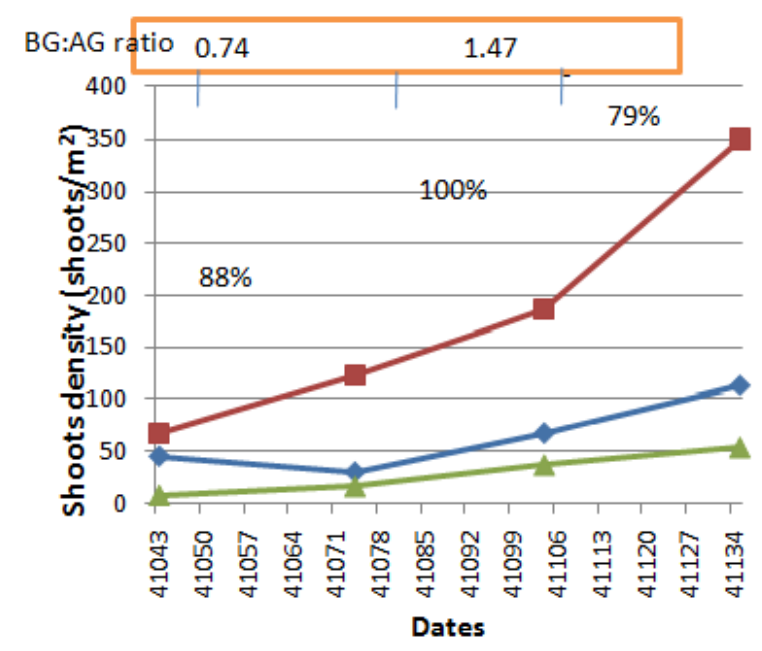

Figure 3. Mean shoot density increase from May 14 to August 14 
than 0.97. The plot of the shoot height in $\mathrm{cm}$ and dry biomass (g) after dried in an oven for all species in Figure 4.

Simple equation developed for predicting biomass of individual plant species with respect to shoot height. The graph curve from Figure 4 showed that when plant height increases the above ground biomass also increases. $157 \mathrm{~cm}$ long Scirpus sp. had 12.14 g dry biomass while Typha sp. had $18.09 \mathrm{~g}$ biomass at $150 \mathrm{~cm}$ height, this difference might be because of the number of leaves on the shoot and the stem diameter.

\section{Evapo-transpiration}

Figure 5 shows that the evapo-transpiration is based on precipitation and temperature of the study area. There was a small precipitation throughout the study period because the study area is mostly dry and $15.6 \mathrm{~mm}$ of rain in August. The wettest time which is $6.16 \mathrm{~L} / \mathrm{m}^{2} . \mathrm{d}$ of rain was occurred in the first week of June. The mean air temperature during the study period ranged from 16 to $32^{\circ} \mathrm{C}$ and the mean reference Penman-monteith $\mathrm{ET}_{0}$ rate ranged from 1.95 to $4.25 \mathrm{~L} / \mathrm{m}^{2} . \mathrm{d}$.

The value of water loss obtained from the control was $1.92 \mathrm{~L} / \mathrm{m}^{2}$.d, which was slightly lower than the average reference ETo $3.12 \mathrm{~L} /$ $\mathrm{m}^{2}$.d calculated from meteorological data. This was because maintaining water level below the surface (subsurface water level) reduces the evaporation. The level of wastewater decreases every two or three days because of high evapotranspiration rates. Typha $s p$. had the highest evapotranspiration rate compared to the other species, which is $5.42 \mathrm{~L} / \mathrm{m}^{2}$.d. This was three times higher than the rate of water loss from the control mesocosms. These indicate that Typha
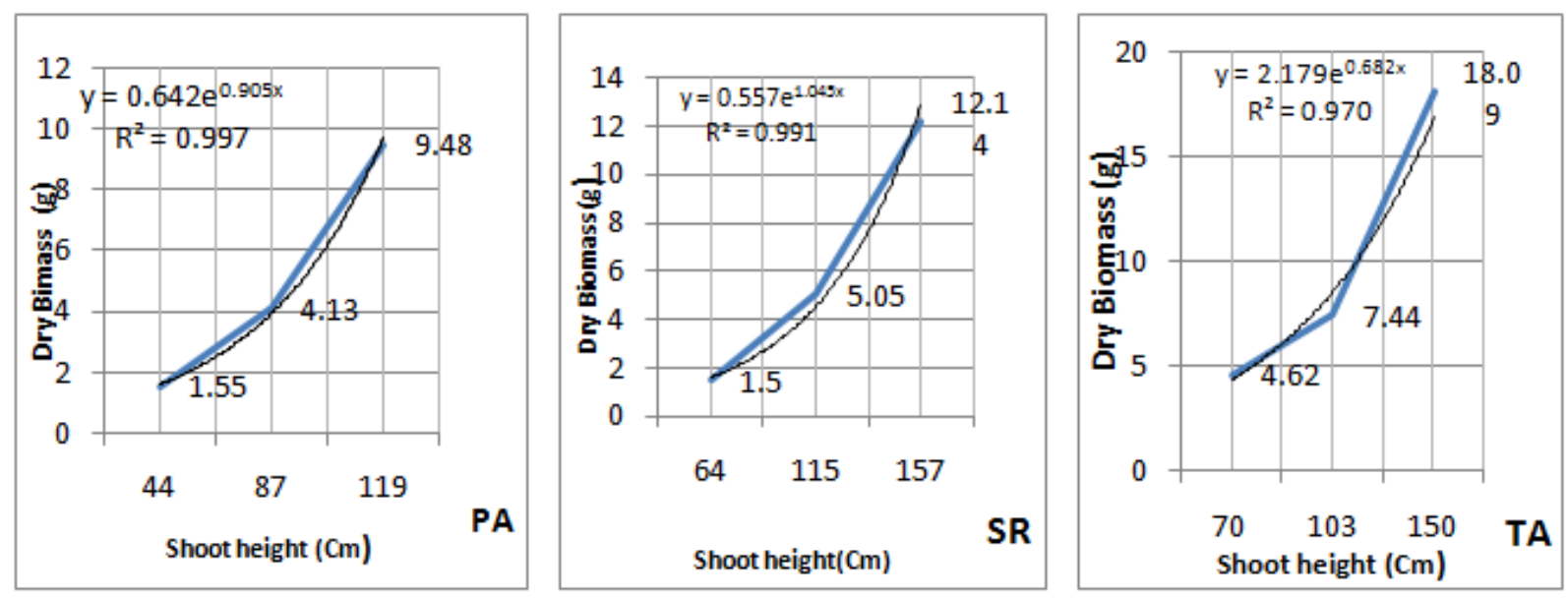

Figure 4. Shoot height and dry biomass relationship for Phragmites, Scirpus and Typha respectively

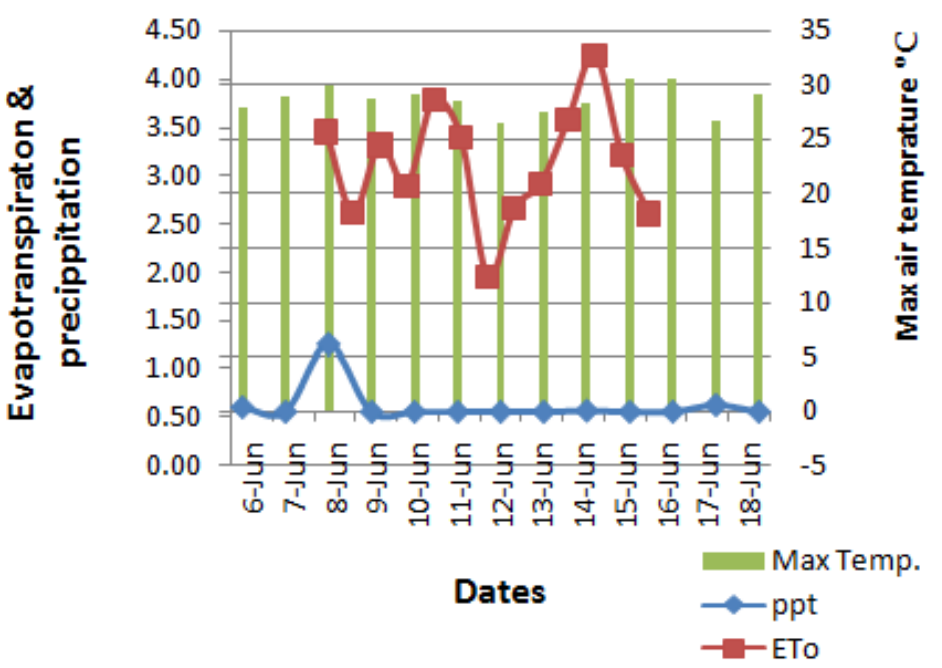

Figure 5. Reference evapotranspiration, mean max temperature and precipitation during the study period of water balance measurement 
$s p$. had the highest growth rate and uses more water than the others.

The two species Scirpus riparius and Phragmites australis had slightly the same evapotranspiration rate, which is 3.18 and $3.19 \mathrm{~L} / \mathrm{m}^{2}$.d. Two days of the lowest evapotranspiration rate with days of $12^{\text {th }}$ and $28^{\text {th }}$ of June because of high precipitation on these days (Fig. 6). Evapotranspiration was very small nearer to zero. Evapotranspiration (ET) process of plants is controlled by several factors. Besides the physiological factors of plants, height, density, LAI (leaf area index), etc., the change of meteorological factors, such as radiation, temperature, wind and precipitation can influence ET process [Zhiwen et al., 2006]. For a given leaf area, narrow leaves are found to have lower evaporation rates as compared to broad leaves [Dunbabin and Bowmer, 1992] due to the thicker boundary layer of nonmoving air on the narrow leaves. Therefore, the differences in shapes of the species leaves may also have an influence on the ET rates. Typha sp. had high evapotranspiration rate than Phragmites Sp. and Scirpus sp. This might be because of long and narrow leaves it generated as well the weather condition in ArbaMinch.

\section{Crop coefficient analysis}

Evapotranspiration rate and crop coefficient trend line look the same. Crop coefficients of all species were lower than 2. Typha sp. had the highest crop coefficient of 1.77. Because Typha sp. had higher Evapotranspiration rate than all species, which is greater than reference ET. Phragmites $S p$. and Scirpus sp. had almost the same crop coefficient of 1.04 and 1.05 , respectively.

Figure 7 shows that the variances for crop coefficient are significantly different, because the significance was 0.033 which is less than 0.05 . Crop coefficient of Typha sp. was significantly different from Phragmites a., Scirpus sp. and control. Crop coefficient and evapotranspiration rate had directly proportional relationship to each other. When evapotranspiration increases, crop coefficient also increases. The SPSS (Statistical Package for the Social Sciences) result of crop coefficient was also the same with evapotranspiration rate results.

The $\mathrm{F}$ value for crop coefficient was 10.455 and the significance was 0.00 (ANOVA Table 2 ANOVA Crop co-efficient). That means there is a significant difference between the groups (the significance is less than 0.05). The trend of plot for mean of crop coefficient and water balance for the three species was quite the same. The SPSS output summarizes the results of the multiple comparisons procedure. The means listed in each subset column are not statistically reliably different from each other. Mostly Phragmites and Typha were statistically significant.

\section{EVAPOTRANSPIRATION}

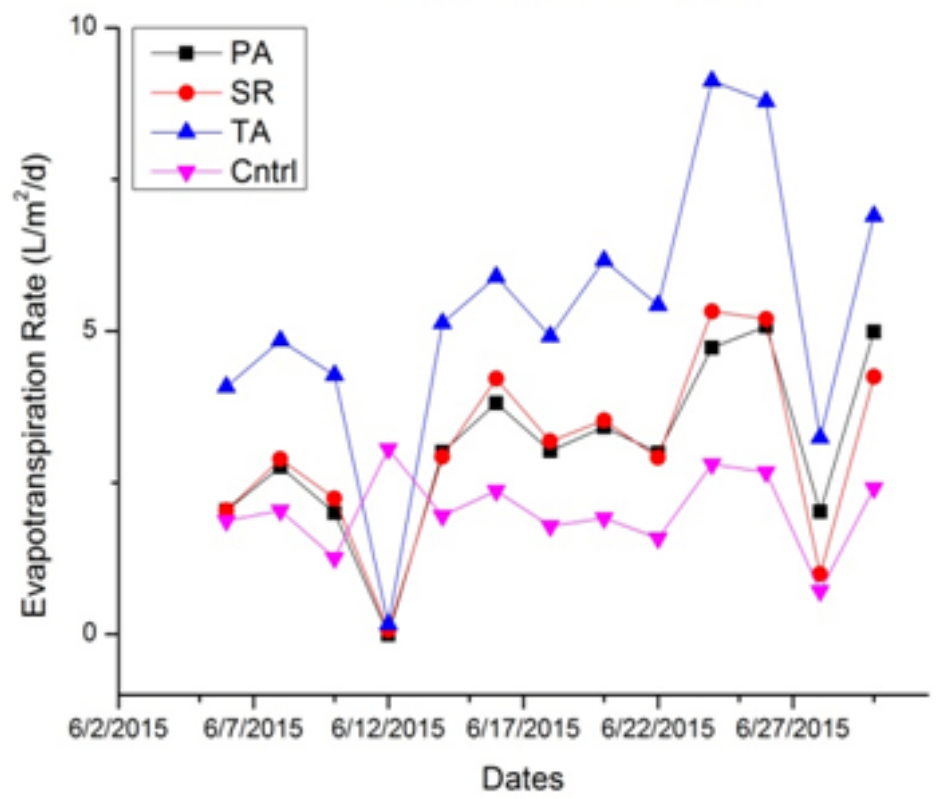

Figure 6. Evapotranspiration rates of the three wetland species and unplanted control. Water balance measurement was done for June 


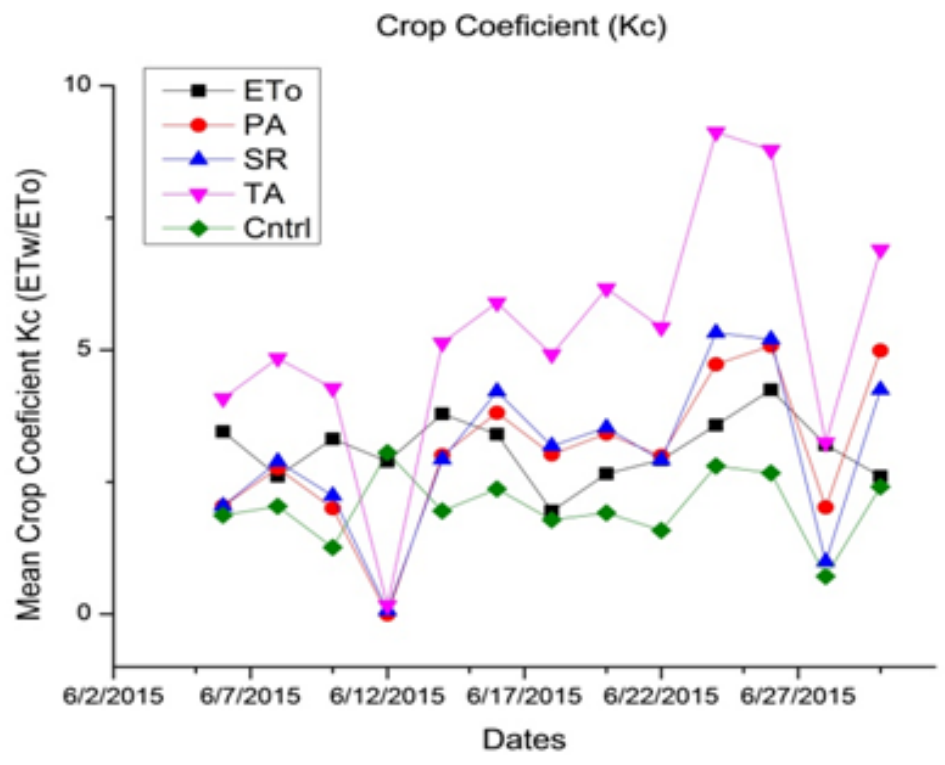

Figure 7. Crop co-efficient for all species and unplanted control

\section{Water use efficiency}

Water use efficiency (WUE) was determined for the three plant species. In order to do that above ground biomass was taken on June 4 and on June 30 . There was a continuous water balance measurement simultaneously. Scirpus $s p$. had a high WUE $4.59 \mathrm{~g} / \mathrm{L}$. This was due to Scirpus $s p$. had the second highest biomass but no excessive ET rate. WUE of Phragmites Sp. and Typha sp. were 4.43 and $2.53 \mathrm{~g} / \mathrm{L}$ respectively (Fig. 8).

Typha $s p$. had low water use efficiency than the other two plant species. Low WUE of wetland plants was due to extremely high water consumption, whilst the biomass was very high too [Vymazal, 2005] ANOVA result of water consumption indicated that Typha sp. was statistically different from Scirpus sp. and Phragmites $S p$.

\section{Nutrient removal}

According to Table 2 nitrate and ammonium removal is greater in Phragmites australis compared with other species. Potassium and organic nitrogen removal is greater by Scirpus Species than the remaining species. Phosphates, calcium, magnesium, $\mathrm{BOD}_{5}$ removal is greater by Typha Species compared with other species. Control or mesocosms without plants remove pollutants in the wastewater due to the attachment of nutrients on the surface of the gravel media and act as a filter. In subsurface flow constructed wetland nitrification can occur in the oxygenated zones within the rhizosphere of plant roots [Tanner, 2011]. Ammonium pathway is biological uptake. This nitrification and biological uptake are the major mechanisms to remove Ammonium from

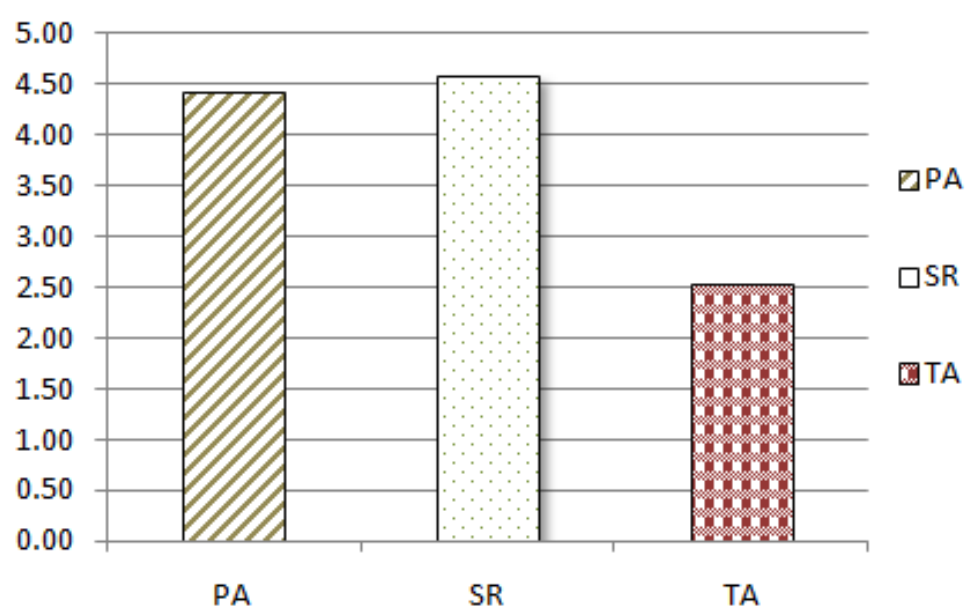

Figure 8. Water use efficiency of each species during the study period 
Table 2. ANOVA crop co-efficient

\begin{tabular}{|l|c|c|c|c|c|}
\hline \multicolumn{1}{|c|}{ Parameter } & Sum of Squares & df & Mean Square & F & Sig. \\
\hline Between Groups & 8.724 & 3 & 2.908 & 10.455 & 0.000 \\
\hline Within Groups & 13.352 & 48 & .278 & & \\
\hline Total & 22.076 & 51 & & & \\
\hline
\end{tabular}

the domestic wastewater by plant species in constructed wetlands. Unlike most terrestrial plants, many aquatic plants use ammonium as a nitrogen source [Kadlec et al. 2009; Brix, 2003]. As in Figure 1 (percentage removal), all the species remove more than $93 \%$ of ammonium from the domestic wastewater in 5 days retention time. The longer the period of contact time between wastewater, plant and substrate, the more effective it is for the removal of ammonium. Long wastewater retention times are presumed to lead to more effective removal of particulate matter [Brix, 2003].

Organic matters in domestic wastewater are mostly dominated by readily biodegradable organic matter which is amenable to biological decomposition within a short hydraulic retention time. The results indicate that the effectiveness of constructed wetland using various plant species is appreciable. Typha species remove the higher percentage of $\mathrm{BOD}_{5}(93.88 \%)$ from the domestic waste water than Scirpus and Phragmites. This is due to the media and macrophytes roots in subsurface flow may provide a greater number of small surfaces, pores and crevices where treatment can occur. In this constructed wetland Typha Sp. most effectively removed Phosphates (99.1\%), Calcium (55.2\%), Magnesium $(81.1 \%)$ and $\mathrm{BOD}_{5}(93.88 \%)$ respectively.

The performance of wetland depends upon the inflow rate, outflow rate, pollutant loading rate, hydraulic retention time (HRT), hydraulic loading rate, climatic conditions, temperature, $\mathrm{pH}$, oxygen availability, wetland design compo- nents substrate, vegetation and living organisms. Scirpus Sp. is more effective to remove potassium and organic nitrogen than Phragmites and Typha. As the observations and the results show (Table 3 ), the most effective in removal of pollutants as well as relevant to this tropical region is Typha.

\section{CONCLUSION}

Phragmites Sp., Scirpus Sp. and Typha Sp. were the plant species which are better adapted to domestic wastewater in terms of survival and proliferation in ArbaMinch Climate. CWs with subsurface flow seem to be a feasible alternative for reducing the nitrates and organic matter content from domestic waste water, being able to tolerate fluctuations of inflow, including feed interruptions. Nutrient removal is very high when compared with the removal efficiencies achieved for nutrients and BODs. As for the results and removal performance, the best suitable species among the three is Typha Sp. in ArbaMinch weather conditions as well.

\section{REFERENCES}

1. Al-Omari A., Fayyad M., 2003. Treatment of domestic wastewater by subsurface flow constructed wetlands in Jordan. Desalination 155, 27-39.

2. Ojstrsek A., Fakin D., Vrhovsek D., 2007. Residual dyebath purification using a system of constructed wetland. Dyes and Pigments 74, 503-507.

Table 3. Pollutants removal by various species using in constructed wetland

\begin{tabular}{|l|c|c|c|c|c|}
\hline \multirow{2}{*}{ Parameter } & \multirow{2}{*}{$\begin{array}{c}\text { Influent concentration } \\
(\mathrm{mg} / \mathrm{L})\end{array}$} & \multicolumn{3}{|c|}{ Effluent concentration (mg/L) from various species containers } \\
\cline { 3 - 6 } & 0.311 & Control & Ps & Ss & Ts \\
\hline Nitrate & 70.15 & 0.269 & 0.154 & 0.180 & 0.175 \\
\hline Ammonium & 12.65 & 2.056 & 1.116 & 0.377 & 0.115 \\
\hline Phosphate & 19.62 & 15.23 & 9.68 & 12.45 & 8.79 \\
\hline Calcium & 67.65 & 59.00 & 46.90 & 28.75 & 12.81 \\
\hline Magnesium & 25.2 & 26.29 & 15.21 & 5.74 & 7.05 \\
\hline Potassium & 146.6 & 33.48 & 20.45 & 19.79 & 6.20 \\
\hline BOD $_{5}$ & - & 11.2 & 5.04 & 3.36 & 4.48 \\
\hline Organic nitrogen & & & &
\end{tabular}


3. Antoniasdis A., Takavakoglou V., Zalidis G., Poulios I., 2007. Development and evaluation of an alternative method for municipal wastewater treatment using homogeneous photocatalysis and constructed wetlands. Catalysis Today, 124, 260-265.

4. Brix H., Arias C. and Johansen N.H., 2003. Experiments in a two-stage constructed wetland system:nitrification capacity and effects of recycling on nitrogen removal. In: Wetlands: Nutrients, Metals andMass Cycling, J. Vymazal, (ed.), Backhuys Publishers, Leiden, The Netherlands, pp. 237-258.

5. Chi-Yuan Lee, Chun-Chih Lee, Fang-Yin Lee, Szu-King Tseng, Chiu-Tung Lia, 2004. Performance of subsurface flow constructed wetland taking pretreated swine effluent under heavy loads. Bioresour. Technol. 92, 173-179.

6. Ciria M.P., Solano M.L., Soriano P., 2005. Role of marchophye Typha latifolia in a constructed wetland for wastewater treatment and assessment for its potential as a biomass fuel. Biosyst Eng. 92(4), 535-544.

7. Tanner C.C., Headley T.R., 2011. Components of floating emergent macrophytes treatment wetlands influencing removal of storm water pollutants. Ecol. Eng. 37, 474-486.

8. Calheiros C.S.C., Rangel A.O.S.S., Castro P.M.L., 2007. Constructed wetland systems vegetated with different plants applied to the treatment of tannery wastewater. Wat. Res. 41, 1790-1798.

9. Daniels R., 2001a. Enter the root-zone: green technology for the leather manufacturer, part 1 . World Leather 14 (4), 63-67.

10. Daniels R., 2001b. Enter the root-zone: green technology for the leather manufacturer, part 3. World Leather 14 (6), 85-88.

11. Dong Qing Zhang, Jinadasa K.B.S.N., Gersberg R.M. , Yu Liu, Wun Jern Ng, Soon Keat Tan, 2014. Application of constructed wetlands for wastewater treatment in developing countries e A review of recent developments (2000-2013). J. Environ. Manage. 141, 116-131.

12. Day J.W. et al., 2004. The use of wetlands in the Mississippi Delta for wastewater assimilation: a review. Journal of Ocean and Coastal Management, 47, 671-691.

13. Drio A., Frost C.A., Smith K.A., Grace J., 1997. Phosphate and ammonium removal by constructed wetlands with horizontal subsurface flow, using shale as a substrate. Water Sci. Technol. 35 (5), 95-102.

14. Grafias P, Xekoukoulotakis N.P, Mantzavinos D.E., Diamadopoulos E. 2010. Pilot treatment of olive pomace leachate by vertical-flow constructed wetland and electrochemical oxidation: an efficient hybrid process. Water Res., 44, 2773-2780

15. Headley T, Fonder N, 2010. Systematic nomenclature and reporting for treatment wetlands. In: J. Vymazal (Ed.), Water and Nutrient Management in Natural and Constructed Wetlands, Springer, Dor- drecht, The Netherlands, pp. 191-220

16. Dunbabin J.S., Bowmer K.H., 1992. Potential use of constructed wetlands for treatment of industrial wastewater containing metals. Sci. Total Environ. 111(2-3), 151-168.

17. Kadlec R.H., Wallace S., 2009. Treatment Wetlands. CRC Press, Boca Raton, FL. Luoma, S.N., 1983. Bioavailability of trace metals to aquatic organisms a review. Sci. Total Environ. 28, 1-22.

18. Keffala C., Gharbi A. 2005. Nutrient and bacterial removal in constructed wetlands treating domestic wastewater. Desalination 185, 383-389.

19. Kucuk O.S., Sengul F., Kapdan I.K., 2003. Removal of ammonia from tannery effluents in a reed bed constructed wetland. Water Sci. Technol. 48(1112), 179-186.

20. Mantori P., Marmiroli M., Maestri E., Tagliavimi S., Piccinini S., Marmiroli N., 2005. Application of a horizontal subsurface flow constructed wetland on treatment of dairy parlor wastewater. Bioresour. Technol. 88, 85-94.

21. Ruan X., Xue Y., Wu J., Ni L., Sun M., Zhan X., 2006. Treatment of polluted river water using pilotscale constructed wetlands. Bulletin of Environmental Contamination and Technology 76, 90-97.

22. Sala M.M., Jurgens K., 2004. Bacterial growth on macrophyte leachate in the presence and absence of bacteriorous protists. Arch. Hydro. Biol. 161, 371-389.

23. Scholz M., Sadowski A.J., Harrington R., Carrol P., 2007. Integrated constructed wetlands assessment and design for phosphate removal. BIOSYST ENG97. 415-423.

24. Shuh-Ren Jing, Yin-Feng Lin, Der-Yun Lee, TzeWen Wang, 2001. Nutrient removal from polluted river water using constructed wetlands. Bioresour. Technol.76. 131-135.

25. Nerrala S., Nearer R.W., Lesiker B.J., Persyn R.A., 2000. Improvement of domestic wastewater by subsurface flow constructed wetlands. Bioresour. Technol. 75. 19-25.

26. Saarinen T. 1996. Biomass and production of two vascular plants in a boreal mesotrophic fen. Can. I. Bot. 74: 934-938

27. Sawaittayolthin V., Polpvasert C., 2007. Nitrogen mass balance and microbial analysis of constructed wetlands treating municipal landfill leachate. Bioresour. Technol. 98, 565-570.

28. Shubiao Wu, Brix P.K.H., Vymazal J., Renjie Dong, 2014. Development of constructed wetlands in performance intensifications for wastewater treatment: A nitrogen and organic matter targeted review. Wat. Res. 57, 40-55.

29. Zhiwen Song, Zhaopei Zheng, Jie Li, Xianfeng Sun, Xiaoyuan Han, Wei Wang, Min Xu, 2006. Seasonal and annual performance of a full-scale constructed wetland system for sewage treatment in China. Ecol. Eng. 26(3), 272-282. 